\title{
Covid-19 vaccine, apartheid and xenophobia: no need to panic!
}

Editor In Chief African Health Sciences

James Tumwine

DOI: https://dx.doi.org/10.4314/abs.v21i4.1

Cite as: Tumwine JK. Covid-19 vaccine, apartheid and xenophobia: no need to panic! Afri Health Sci. 2021;21(4): i. bttps://dx.doi. org/10.4314/abs.v21i4.1

Welcome to this December issue of African Health Sciences in our $21^{\text {st }}$ year of publication. We bring you papers largely on infectious disease which range from Covid-19 to HIV. Interesting, because Covid-19 has reached a watershed, with the announcement of a new variant (Omicron), that has exposed the discriminatory world that had demonstrated vaccine apartheid, and now infectious disease xenophobia. Ironically both situations have some link with South Africa. The word apartheid was conceived and implemented in racial South Africa, where black people were treated like they were non-human. ${ }^{1}$ When liberation and independence came, the non-South Africans from neighboring countries that had supported the liberation struggle suffered in a wave of xenophobia. ${ }^{2,3}$

And come Covid-19! What happens? The high-income countries buy and hoard vaccines ostensibly to protect their citizens. And when the new Covid-19 variant is detected in southern African countries, what do the high-income countries do? They go into panic mode ${ }^{4}$ and introduce draconian measures to exclude travelers from those countries. Many of those countries have described the action as xenophobia. Unfortunately, Covid-19 and climate change have taught us that this small fragile planet is a small village. When people in one part of the world sneeze all of us are in potential danger. We can pretend that hoarding vaccines or locking out peo- ple whose skin color is different from ours will protect us, but this is a fallacy!

What we need is global unity, solidarity and practice universal ubuntu - a South African word that means "humanity". It is also called the "I am because we are" humaneness that puts people first regardless of their color or creed. Unless we practice ubuntu, we are very unlikely to control this Covid-19 pandemic!

\section{References}

1. Blakemore E. 2019. For decades, the country's Black majority was controlled by racist laws enshrining white supremacy. The Harsh Reality of Life Under Apartheid in South Africa. https://www.history.com/news/apartheid-policies-photos-nelson-mandela Accessed $6^{\text {th }}$ December 2021

2. Bond P, Baruti A, Nokuthula C, and Ngwane T; 2011 "Xenophobia and Civil Society." Politikon 38, no. 1: 5983.

3. Hickel J "Xenophobia" in South Africa: Order, Chaos, and the Moral Economy of Witchcraft. https:// journal.culanth.org/index.php/ca/article/view/ ca29.1.07/281. Accessed $6^{\text {th }}$ December 2021

4. Atkinson E. UK 'panicking unnecessarily over omicron, says doctor who discovered new variant. https:// www.independent.co.uk/news/health/omicron-covid-symptoms-angelique-coetzee-b1965576.html. Accessed $1^{\text {st }}$ December 2021 